\title{
Video Film and African Social Reality: A Consideration of Nigeria-Ghana Block of West Africa
}

\author{
Osakue Stevenson Omoera \\ Department of Theatre and Media Arts, Ambrose Alli University, Ekpoma, Edo State, Nigeria \\ Mobile: 234803571 4679, E-mail:omoera@yahoo.com
}

KEYWORDS Video Film. Nigeria. Ghana. Industry. Audience

\begin{abstract}
Today, video film as a form of media production is very popular in Nigeria and indeed in much of Africa. Nigerian video films, especially those produced in English; enjoy considerable patronage in Nigeria, Ghana, Zambia, Kenya Zimbabwe, England, USA, Italy and many other places. Along with this growing acceptance are questions as regards the video film evolution in the West African sub region. Against this backdrop, the paper adopts the historical, descriptive and analytical approaches as its method of reflecting on how the video film phenomenon emerged in Nigeria, what issues the Nigerian video films busy themselves with, what sort of reception is granted these films in Ghana and why. It concludes by canvassing that governments and other stakeholders in the West African sub region should explore the huge potentiality of the video film industry in creating employment opportunities and redressing contemporary social challenges.
\end{abstract}

\section{INTRODUCTION}

In contemporary Africa one of the greatest pastimes is the video film. It has become a newfound love for the African mind. This is largely due to its accessibility to huge audience, including children and adolescents as compared with an older form of media production like the cinema. Larkin (2002) says:

African video films refer to the rise of filmmaking in Nigeria and Ghana that is shot straight on video, but still referred to locally as "films". These films are not the art cinema more usually seen in Africa film festivals, but truly popular, meaning not only that they command huge African audience, but also that their production and financing is dependent entirely on how well they perform in the market place.

Along with the rise of video film, many people (Africans and non Africans), especially in Nigeria and Ghana are beginning to ask certain questions: How did the video film phenomenon which is fondly referred to as "home video", "nollywood" "naijawood", among others, in the Nigerian media culture emerge? What issues do the home video films busy themselves with? What sort of reception do audiences elsewhere, particularly in Ghana, accord Nigerian video films? And, why do they grant the films such reception? These are the issues this paper wishes to address. African cinema emerged from the crucible of colonialism and the struggle of early independence. The effort to "decolonize the mind" as
Ngugi Wa Thiongo memorably put it, to create an African film practice and a form of mass media production based on African realities and traditions, have been the driving force of the African cinema enterprise. The result of this endeavour is the creation of a solid body of artistic movement. Besides, the rise of film festivals and academic conferences in which films circulate has provided key sites for the ongoing debate among African intellectuals and artists about the nature of African modernity. The painful irony remains though, that films produced under the rubric of African cinema are rarely screened in Africa itself and are thus kept from reaching the masses that often form their subjects. This sorry state of African cinema or films shot on celluloid is partly due to the fact that the medium of mass communication calls for mega budgeting. Most African economies cannot sustain the business of cine filmmaking as a medium of mass culture because they are economically anaemic. Also,

... while African cinema has flourished in New York, London, Paris and elsewhere, it has rarely been screened in much of Africa itself even in Quagadougou, the runaway success story of African cultural festivals, for two weeks every two years the cinema screens are filled with the best work of African filmmakers.Outside of the festival, however, the screens revert to the French, American, Hong Kong and Indian films watched by the vast majority... (Larkin 2002).

On the other hand, the video film or films shot 
on electromagnetic tape is readily produced with a shoestring budget. Apart from the inexpensive nature of this form of media production, the masses in much of Africa, especially Ghanaians and Nigerians are readily reached. The video film has thus become very popular amongst Africans. Interestingly too, it has become a veritable expression of African modernity in terms of mass culture. Looking at both forms of mass media production from the standpoints of economics of scale and production output could be revealing as well as instructive. In Africa, video films are easily and readily produced as against that of traditional cinema. Larkin points out:

In 1999 over 50...video films were produced in Ghana and over 500 in Nigeria. This means that, in this one year alone; more video films were produced than in the entire history of feature film production in these countries. From almost nothing 10 years ago, video films have blossomed to become perhaps the mostvibrant new form of media production in Africa (2002).

Similarly, Ekwuazi contends that: ...the Nigerian home video has spawned an industry that: turns out 1000 films every year, generates 300,000 jobs every year, has a turnover of well over $\$ 5$ Billion yearly: with a growth rate of some $06 \%$, the industry is bursting at the seams (2003). These groundbreaking achievements of the video film as against the lethargy of celluloid film as forms of media production in Africa indicate a call for an urgent revision of the concept of filmmaking in the continent. Again Ekwuazi's position seems to tie up with foregoing:

Perhaps, there is no better way to begin to dispose of some red herrings. Film is film and video is video - and never the twain shall meet. False. Modern technology is fast dissolving the difference between both formats. So much so that to perceive or assume any difference in image resolution is to make a distinction without difference. And both in production and post production, but even the more so in the latter, there is a markedly high level of complementarity of both formats. So, in the modern context, film is exclusively neither celluloid nor video, it is either: It is the motion picture, whether projected on the small or large screen (2003).

From the foregoing, it would be right to argue that film shot straight on video has come of age in Africa and has also 'become one of the most dialogued issues in mass culture' Ekwuazi (2003).

\section{THE EMERGENCE OF VIDEO FILM IN NIGERIA}

Historically, the evolution of the video film has come a long way. On the African scene, the emergence of the video film is traceable to Nigeria. Its evolvement is rooted in the various advances made with the feature film. Over the years, it became apparent that films projected on the big screen, were inadequate for entertaining the teeming masses who sought to enjoy motion picture presentations in the warmth of their homes. "Videographers, therefore resorted to motion picture locally recorded on plastic magnetic tape" (Nwabuzor 2001). Today there is a deluge of movies produced in six major Nigeria languages Hausa, Yoruba, Igbo, Edo, Tiv, Efik. This is aside English / pidgin language video films .According to Adesanya,

Basically, video production started in the late eighties out of a desperate desire by producers to remain in the motion picture business and this was on a shoestring budget. Initially the target audience was to be found in one-room screening centres and mushroom halls equipped with a television set and a VHS player (2000).

Video film has since grown into a bustling industry and has been described as "the contemporary equivalent of the Onitsha market literature (OML)" (Akinosho 2002). This comparison is perhaps borne out of the nature of the reception (extremely popular), the marketing (mass) and most importantly the titling of the OML, which is replicated and even amplified in the home video today. Within a few years, the video film culture experienced a dramatic upsurge in Nigeria. .Ojo-Rasaki contends that three things are chiefly responsible for this:

First, is the ever-increasing popularity of television medium. Second, is the fact that nightlife has become very unsafe in Nigeria due to criminal activities and also the cinema halls have become rough and unsafe. Third, is the effect of capitalism which keeps parents away from their kids most of time. Such kids, who find solace in the video film, stay glued to the screen and become video-addicted (2001).

Ojo-Rasaki's argument though correct, seems to lay more emphasis on social reasons for the upsurge. However, economic reasons are equally compelling. In this regard, Ekwuazi (2003) observes: 
With the Structural Adjustment Programme (S A P), things fell apart and the centre (the cine film) could no longer hold. For with lack lustre performance of the Naira in the international marketplace, films, rawstock and the rest could no longer come into the country: Like a pack of cards, cinema theatre started tumbling into closure. A yawning vacuum was thus createdwhich the practitioners of the Yoruba travelling theatre, who had made transition via television to film, through the pioneering works of Ola Balogun and Bankole Bello, rushed to fill-with the reversal film. And so, through the reversal to the home video, was almost in a natural progression.

Ekwuazi's position dovetails with Nwabuzor's contention that: With the advent of time, monopoly, lack of adequate funds and high production costs combined to drive producers into the search for an alternative. The result was reliance on reversal film stock and video cassette format (2001).

\section{VIDEO FILM VIS-À-VIS SOCIAL REALITY IN AFRICA}

Right from the works of the Yoruba theatre troupes which pioneered the home video movie industry in Nigeria to the immensely proliferated video film production in Africa, there is a mixture of the good, the bad and the ugly in terms of theme and dramatic construct of material. However, this is not the thrust of this discourse. This paper is rather interested in how the Nigeria (African) video films portray social reality. Against all expectations, the African video film has marginalized, even the American film especially in Nigeria, Ghana and all over the West African coast. This perhaps accounts for the attention being paid to it by the Western media such as the 'Washington Post', 'Time Magazine', 'African Film Festival, New York', to mention but a few. It has also been noted that Nigeria accounts for over $80 \%$ of video films produced in Africa. The major centres of production of video films in the country as identified by Ekwuazi are Lagos (Idumota Street), Onitsha (Iweka Road) and Kano (2007). Interestingly, Benin, Calabar and MarkudiJos axes are fast becoming major centres too. These six points of release incidentally represents the six major languages. As a means of portraying social reality, 4 dominant categories have been identified by Ekwuazi (2003), viz: rags to riches, the epic, Pentecostalism and the comic. However, it is imperative to state that a general survey of video films done in English language/pidgin forms the basis of discussing contemporary African issues in this paper. Most of the home videos produced in English are often melodramatic. They are set in metropolitan centres. In their style and themes, the video films owe more to Western soap operas than they do to earlier generations of African cine films. In this regard, Larkin (2002) notes that:

The camera lingers on shots of Mercedes Benz, mobile phones, huge bungalows and expensive dress of a world that only a tiny minority of Nigerians or Ghanaians (Africans) can afford. The narrative is propelled through a series of shocking events and films and characters become known for their ability to outrage the audience (Parenthesis mine).

"Diamond Ring I and II" "Out of Bounds", among others, directed by Tade Ogidan are classical examples of the melodrama that dominates English language videos. "Out of Bounds," for instance, opens with a scene of a Pentecostal pastor played by a popular actor, Richard Mofe-Damijo (RMD) healing one of his congregation members through the power of prayer. Afterward a member of his congregation appears on television to testify of this miracle. The size of his congregation increases, prominent people in society seek his help and offer support and he becomes wealthy and famous. For the next two hours the film explores the consequences of this success. These include sexual immorality, financial impropriety, to mention but a few. In many respects, "Out of Bounds" follows the pattern of many Nigerian English language video film. Many of these films ("The Pope Must Hear This", "Executive Crime", "Emotional Tears", "Keeping Faith", "Emotional Crack", "Shattered Illusion", among others) are set within the world of Nigerian urban elite. That world is rich, cosmopolitan and corrupt and the films explore this corruption and other moral failings of the elite in vivid detail. Transgression dominates and the films place characters in situations where everyday moral etiquette is outrageously flouted. At the end, the evil are punished and good wins out but in the two hours in between, men betray their wives, women trade sexual favours for money, the young disparage the old and the old become corrupt and evil.

On another plane, everyone, it seems, is 
prepared to make use of witchcraft or pacts with the occult or cult groups in order to go ahead. This is often a major anvil on which most video films are forged. In "Living in Bondage", directed by Kenneth Nnebue, "Nneka the Serpent", "Blood Money", "Sakobi the Snake Girl", "Snake Kingdom”, "Agum”, "Out of Bounds", "Diamond Ring" I and II , among others, this scenario plays out. In "Out of Bounds", Pastor Voke is called upon by a chief to counsel his daughter, Tutu. Away from her father's presence, Tutu flouts Christian mores by dressing irresponsibly, sleeping around with men and taking drugs. Voke tries to win her back to Christ but instead Tutu seduces him and she becomes pregnant. At the end of the film, Tutu repents as she is dying in hospital and Voke, humiliated and reduced to penury, turns back to Christ and dedicates himself to preaching to the poor.

As in their American counterparts, conflicts in the family, desire for wealth, betrayal, and so forth, are key themes but with solid African twists - the mixing of horror and magic in melodrama. Wealth in video films oftentimes is made through evil, magical practices. Drawing on popular rumours and widespread folk beliefs, video films bring to life common stories about human sacrifice and pacts with witches out of which money comes. Most of the video films in Africa play up these tendencies. In Ghana/Nigeria film coproduction, "Time" (2000) directed by Ifeanyi Oyeador for instance, a bank manager (Kwame Ansah), falls on hard times makes a pact with a witch in order to become wealthy again. The witch tells him that as he becomes wealthy his wife will fall sick. The more serious her ailment becomes, the wealthier he will be, when she dies he is instructed to keep her body hidden in a closet and as long as he does so, she will spew money from her mouth. A similar sacrifice is demanded in the classic Nigerian video film "Living in Bondage"(1992), where in order to join a cult of rich Igbo businessmen the main character Andy (Kenneth Okonkwo) is told he must kill his wife in a ritual sacrifice for money to accumulate.

In dramatizing the works of witches and the prevalence of human sacrifice, video films move from the world of melodrama into the suspense and gore associated with horror. Nigerian films, in particular, are known for such special effects as humans transforming into animals, witches flying through the night and money being magically produced. The use of shock and desire for notoriety means that many video films are in a constant game of showmanship, each new film trying to be more excessive, or more inventive in its outrage than the last. Larkin observes: It is the mixing of melodrama with horror and magic and the linkage of financial with sexual and spiritual corruption that makes the melodrama of Nigerian and Ghanaian video film distinctively Africa (2002).

In contemporary post colonial West Africa where the everyday suffering of the vast majority stands in stark contrast to the fantastic accumulation of the small elite, the antics of sorcery, witchcraft and supernatural evil have provided a powerful way to express inequalities of wealth. Representations of magic and the supernatural are not escapist fantasies but are believed by audiences to be part of the everyday world. The films draw on this existing belief and give it dramatic, narrative form by pulling together ideas of cosmopolitanism, westernization, wealth and magic that has made these and other Ghanaian and Nigerian films strikingly successful.

The epic genre parades titles such as "Battle of Musanga" directed by Bolaji Dawodu, "Igodo" and "Eziza" by Pedro Agbonifo-Obaseki, among others. Comic films include "Osuofia in London" "De Don and Capo" "Aki and Pawpaw" directed by Andy Chukwu, amongst many others. Though popular amongst the masses, some stakeholders and opinion leaders contend that most of the videos re-enact histories and contemporary issues in a rather skewed manner and play up the buffooneries of comic characters to insult the sensibilities of the viewers. Roseline Udeh, formerly of the National Film and Video Censors Board (NFVCB) in Nigeria for instance, is always quick to point out that most of the films fall short of being good representations of African heritage and modernity (Nigerian Television Authority (NTA) Network News, 19 July, 2004). Similarly, Okey Ndibe maintains that:

... the quality of most of these home videos leaves much to be desired. Purveying rank superstition, a landscape peopled by serpents, witches and other demonic chimera, a good deal of the videos help foster a descent into anachronistic supernaturalism by a growing number of Nigerians. They hack back to the idea of Africa as the theatre of the weird, the bizarre, the deformed and the fantastical (2004).

Others insist that the videos are on the right track. The observation of a Nollywood actor/ 
director, Ejike Asiegbu, in respect of the foregoing, is illuminating. The video filmmaker argues that the business of video filmmaking is "...all about story telling; trying to recreate a societal situation. If you are telling a story of a prostitute, you must create a character and this character chiefly derives from the society. If you cut off this link, you are impinging on creativity" (NTA Network News, 19 July, 2004). In other words, Asiegbu believes that the society fuels the creativity of the videographers and what they in turn produce are concrete reflections of the society. However, it is instructive to note the proposition of Silas Yisa, formerly of National Broadcasting Commission (NBC) in Nigeria. He states that " $80 \%$ of the Nigerian video films are good... and what is now needed is a concerted effort on the part of the practitioners to cut out all the undesirables that tend to portray the country in bad light" ( NTA Network News, 19 July, 2004). The foregoing observations point to one fact: video film in English is very popular in Nigeria and indeed in much of Africa. From Kenya to South Africa, Ghana to Zambia, Gambia to Zimbabwe, video films are received with delight.

\section{THE RECEPTION OF NIGERIAN VIDEO FILM IN GHANA}

Without doubt video film has developed a huge followership in terms of audience reception within and outside the shores of Nigeria. Today, Nigerian video films, especially those produced in English; enjoy considerable patronage in Ghana, Kenya, Zimbabwe, Zambia, England, the U.S, Italy and elsewhere (NTA International News, 11 August, 2007). With the growing acceptance of these video films, film making business in Africa seems to be undergoing a redefinition. Larkin (2002) contends that: What we are seeing is the emergence of a new order of African film that exists almost wholly outside of the structure associated with the paradigm of African cinema. However, the Nigeria-Ghana block in terms of this paradigm shift; in terms of video film production and video film reception further excites this paper. Video films produced in Nigeria enjoy wide acceptance and patronage in Ghana because they expressly portray social reality.

Most Nigerian video films in English resonate well with what occupies the minds of people in contemporary postcolonial West Africa. Film producers cash in on the popularity of these subjects and give them dramatic twists in the narrative plots of their works. Video films treatment of these subjects give the masses in Lagos, Accra, Kumasi, Onitsha, Takoradi, Benin, Port Novo, Port Harcourt, Jos, Akwanga, and many other urban, suburban and village centres across the West African coast a vicarious satisfaction, hence, home video movies are well received in these places. Coupled with the foregoing is the fact that Nigerian videographers amply use special effects.

The common lingua franca shared by Nigeria and Ghana as a result of similar colonial experience has made the warm reception of videos from the former to the latter possible. Although, different local languages / ethnic groups exist, the Nigerian / Ghanaian mass audience cannot simply be pinned down to a distinct social category. This is because a majority of them fit into the mass phenomenon which encompasses the lower urban and (aspiring) middle classes who understand English language or at least its local variant, Pidgin English. Incidentally, the main language spoken in many Nigerian video movies is English / Pidgin. It cuts across ethnic divisions and, of course, movies produced in English / Pidgin are easily and readily watched by audiences whose mother tongues are different. Successful Nigerian movies like "Out of Bounds", "Living in Bondage" have been watched by more than 30,000 people in Accra's various cinema centres and suburbs, and have become the talk of the town (Meyer 2003).

Besides, economic factors have also influenced Ghanaian audiences in receiving Nigerian video films. With the increasing liberalization of trade across the west coast by Economic Community of West African States (ECOWAS), the informal sector of video film production, distribution and exhibition has been boosted in the sub region. Nigerian motion picture producers / marketers like Snude Entertainment, Opa Williams, Wale Adenuga productions, Tunde Kelani's Mainframe productions and many others have been able to establish distribution / exhibition outlets in and outside the country. In major urban centres like Lagos, Onitsha,(Nigeria), Accra, Kumasi, Takoradi, (Ghana), most films are given rave media reviews ( in newspapers, on radios and television), initial theatrical release in video parlours and simultaneously made available on video cassettes / tapes / VCDs, and other formats. This way, mass audience; in Ghana / 
Nigeria are presented with cheap and accessible alternatives to pick from. Those who are too poor to afford a television set and video recorder visit video parlours where they watch movies for token fees. Those who can afford them go for the cassettes / VCDs and watch within the comforts of their homes. Marketers of Nigerian movies have successfully exploited these inexpensive choices of selling videocassettes / screening in video parlours to win the teeming patronage of Ghanaian audiences.

Furthermore, the growth of star syndrome in video films in West Africa has impacted on the nature of Ghana audience's reception of Nigerian films. In Nigeria, popular video actors / actresses like Richard Mofe- Damijo, Nobert Young, Liz Benson, Segun Arinze, Kate Henshaw, Genevive Nnaji, Jim Iyke, Hilda Dokumbo, Zack Orji, Ramsey Noah, Pete Edochie, and a host of others have over time built huge and enthusiastic followership across West Africa and beyond. In Ghana like in Nigeria, millions of fans are always excited to see their favourite Nollywood actors / actresses. And cashing on this, video film producers feature these stars along with known Ghanaian stars like Emmanuel Kwame, Veronica Quashie, Kalsoum Sinare, Dugbartey Nanor, Sam Nai and others to have a permanent hook on the pockets of the audiences. A majority of the Ghanaian audiences itch to see Richard Mofe Damijo, Buki Ajayi, Stephnie Okereke, Stella Damascus, Omotola Ekeinde, Bimbo Akintola, Jim Iyke, Francis Duru, Liz Benson or Segun Arinze, hence, they receive movies featuring them with the warmest embrace.

Similarly, the costume and sense of fashion of Nigerian video film stars have become a reference point for mass audiences across the west coast. The actors/actresses exhibit, in the apparels and other accessories they wear, elitist tastes of modern bank executives, 21st century dudes and gals, and business men who live in well furnished homes, drive flashy cars and talk big. Though a majority of the Ghanaian audiences may not or may never be able to live in such opulence they see in these films, they nevertheless, are satisfied by just whetting their appetites. This sort of disposition also accounts for the overwhelmingly lovely reception Ghanaian audiences give Nigerian video films.

Other aspects of the aesthetic construct of Nollywood such as music, locale of shoot, and the rest, however scrappy they may be, have made Nigeria movies to buy into the Ghanaian psyche. The wide gamut of music-Highlife, Hiphop, Reggae, Afrobeat Jazz, Makosa , Juju, Fuji, among others, which intersperse and sometimes reinforce the themes of the movies besides the panoramic sceneries, posh buildings and furniture readily appeal to the sensibilities of the average Ghanaian home video "vidiot" (Okhakhu 2003).

\section{CONCLUSION}

The Nigerian video film industry has grown in leaps and bounds. It has received international acceptance and accolades; at least, it has been tagged Nollywood by the New York Time Magazine for being able to replicate the glamour and glitz associated with Hollywood and Bollywood in West Africa and indeed the whole of Africa. From Nigeria to Ghana, Kenya to South Africa, huge audiences are welcoming the Nigerian video films with open arms. This is because the flicks ostensibly portray issues that mass audiences in these countries are familiar with and are ready to identify with. Besides, the ease with which the new media of mass communication is accessed also accounts for its acceptance by the African movie audience. What now remains is that the various governments of Nigeria, Ghana and indeed continental Africa should synergize efforts at supporting the teeming video film industry. The reason being that Nollywood or "Africanwood" is capable of playing a central role in job creation, youth empowerment, poverty alleviation, ethnic/religious conflict resolution and the fight against HIV/AIDS pandemic, if the present artistic, economic, social and cultural structures are effectively and efficiently strengthened. In fact, this paper believes that it is high time champions of programmes/ agencies such as New Partnership for African Development (NEPAD), National Economic Empowerment and Development Strategy (NEEDS), and African Union (AU), among others, whose driving force is the desire to lift up the living standards of Africans explored the tremendous potentialities that abound in the video film enterprise.

\section{REFERENCES}

Adesanya A 2000. From film to video. In: Jonathan Haynes (Ed.). Nigerian. Video Films. Athens, Ohio: Ohio University Centre for International Studies, pp. $37-50$. 
Akinosho Toyin 2002. Artsville: Onitsha literatiure... Onitsha movies. The Guardian, May 26, 2002, P. 39. Austin Gregory 2003. For Nigerian Nollywood the headache is fund. The Guardian, August 14, 2003, P. 43.

Ekwuazi H 1991. Film in Nigeria (2nd Edition). Jos: Nigerian Film Corporation.

Ekwuazi H 2003. $2^{\text {nd }}$ National Film Festival Programmes of Event. Jos: National Film Corporation.

Ekwuazi H 2007. The Hausa video film: the call of the muezzin. Film International, 5(4): 64-69.

Larkin Brian 2002. Popular video film. African Film Festival. New York: African Film Festival Inc., 2002 pp. 1-4.

Nigerian Television Authority 2004. Network news report on the three-day movie industry stakeholders' consultative retreat. Nigerian Television Authority 19 July, 2004.

Ndibe Okey 2004. Again, on the image crisis. The Guardian, August 5, 2004, P. 65.
Meyer B 2003. Ghanaian popular cinema and the magic in and of film. In: Birgit Meyer and Peter Pels (Eds.). Magic and Modernity: Interfaces of Revelation and Concealment. Stanford, CA: Stanford University Press, pp. 200-222.

Nwabuzor M B 2001. Nigerian home video in English and the national interest: the Search for an African identity. Paper presented at the $2^{\text {nd }}$ National Conference on African Dramaturgy and the Black History in Benin City in University of Benin, Benin City, February 25-28, 2001.

Okhakhu M 2003. Contemporary trends in screen movie production. Paper presented at the Department of Theatre Arts and Mass Communication MA Class Seminar in Benin City in University of Benin, Benin City, June 2, 2003.

Ojo- Rasaki Bakare 2001. Character of the Nigerian film. The Guardian, 27 September, 2001, P. 32. 